\title{
The Attitude of Undergraduate Students towards the Use of Journals in Delta State University Library, Abraka, Delta State
}

\author{
Rexwhite Tega Enakrire*, Ejiro Orezimena John \\ Department of Library \& Information Science, Delta State University, PMB 1, Abraka, Delta state \\ enakrire@yahoo.com
}

\begin{abstract}
This study was carried out to look at the attitude of undergraduate students towards the use of journals at the Delta State University Library Abraka and suggest possible ways on how to encourage undergraduate students to make use of journals for their research work and study and also for Delta State University library, Abraka to improve in the services of meeting users information needs. Review of related literature were sourced under the following concepts: the importance of journal awareness among undergraduate students, the acquisition of current journal used among undergraduate students, the relevance of organizing journals among undergraduate students, the challenges encountered by undergraduate students in the use of journals, kinds of journals publication. A descriptive survey research design was used for the study and one hundred and twenty one (121) students were used as respondents who answered the questionnaire posed by the researcher. A simple percentage was used for analysis of data. The research findings revealed that journals are used among undergraduate students and the journals enhance the development of personal philosophy in a code of ethics. Undergraduate students make use of current journals in academic libraries. It therefore shows that undergraduate students benefit from the use of journals in the following ways: Through personal growth and development, intuition and self expression, problem solving, stress reduction and health benefits. Based on the findings, recommendations were made to upgrade the standard of journal use among undergraduate students of Delta State University Abraka, that more current journals should be provided for undergraduate use, that funds are made available to purchase more journals in Delta State University library, Abraka for undergraduate students use.
\end{abstract}

Keywords Use of Journals, Awareness, Undergraduate Students, Organization, Relevance, E-journals, Delta State University Library, Delta State

\section{Introduction}

Journals are a good source of primary information. They are published on a regular basic (usually quarterly for monthly). Some journals publish articles that report on the outcomes of academic research while others provide practical information to practitioners in the field. The library subscribes to a range of journals types from magazine through to journals that details academic research.[31]. To this end,[32], journals could be seen as a bond note, book, a ring binder full of papers, a collection of electrical particles on computer disk or an audio tape, people journal in different ways. At heart, though a journal is a day book, a place to record daily happenings. A journal as further stated by[32], is a tool for self discovery, an aid to concentration, a mirror for the soul, a place to generate and capture ideas, a safety value for the emotions, a training ground for the writer and a good friend in confident. Journals shares same qualities with

* Corresponding author:

enakrire@yahoo.com (Rexwhite Tega Enakrire)

Published online at http://journal.sapub.org/library

Copyright (C) 2012 Scientific \& Academic Publishing. All Rights Reserved things like logs and diary. It records experience and events over a period of time. Writing and keeping journals also entails conscious reflection and commentary.

[14], as cited by[32], pointed that journals are reconstruction of experience and like the diary has both objectives and subjective dimension, but unlike diaries the writer is (or becomes) aware of the difference. The journal as a service broke is implicitly a book that someone returns to. It serves purpose beyond recording events and pouring out thoughts and feelings. Like the diary, the journal is a place to let it all out. But the journal is also a place of making sense of what is out. The journal is a working document.

Journal is an accumulation of materials that is mainly based on the writing process of reflection. It is written over a period of time, not in one go. Putting learning in front of journals implies there is overall intention by the writer (or who set the task) that learning should be enhanced. In the same vein, Moon (2010) and[13] described journal as regular publication that contain articles on current research. Usually, the author of a journal article will have carried out same primary research; perhaps they have carried out a study where they have interviewed as surveyed journal article and 
found the importance in finding support evidence for assignments. Helton emphasized that journals are always published at regular intervals, for example, weekly, monthly, or quarterly, the information they contain is very up to date. Book on the other hand can sometimes take up to 2 or 3 years to be published.

On the other hand, the Free Answer.Com. (2011) define attitude as a settled way of thinking or feelings, typically reflected in a person's behaviour, a position of the body proper to or implying an action or mental state. An attitude is a hypothetical construct that represent an individual's degree of like or dislike for something. Attitudes are generally positive or negative virus of a person, place, thing or event. This is often referred to as the attitude object. Relating the above point, Bolton (2005) noted that the possibilities of journals writing, use and keeping as an aid to the professional development of formal and informal education was recognized by a number of academics and trainers.

There was an emphasis on the use of explorative recording students in the UK form the 1960's on the significant part based on their use. Mainstream teacher educators also began to pick up on the potential of personal professional journal writing. These were also growing attention to the role journal writing in personal growth. As a result, by the end of the century there was a significant journaling industry with a range of books, websites, training programmes and retreats and even specialist software.

Over the years journals have been used as sources of up-to-date and current information. Journals contain write-ups, reports reviews, stories, new discoveries by several contributors. Information contained in them is more current than those in textbooks. In most cases, it is information that appeared in periodicals (which include journals) which are distilled and published in textbooks, (Adomi, 2006). The use of journals by scientists and researchers has developed over the years and during those years journals have evolved in specialized ways to fulfill their primary activities (Llewellyn et al 2002). According to Tenopir and King (2002) "studies conducted over the last four decades shows that scientists, on the average, value journals and journal articles more than any other simple information resource" (P.I). The reasons journals are preferred is not far fetched. Rowland (1997) describes four major functions of a scholarly journal as;

1.1. Discrimination of information (their information can not be discriminated)

\subsection{Quality control (value judgement of Information)}

1.3. Canonical archives(can be stored and retrieved from archives)

\subsection{Recognition of authors (P. 1)(make authors to be known)}

Added to the above is that articles to be published in a scholarly journal are properly filtered by their editorial board. They are peer-reviewed, the authorities of contributors are considered and then they publish articles on related topics
(Tenopir and King 2002). Education involves more than gaining and exercising technical knowledge and skills. It depends on the undergraduate students to cultivating a kind of artistry. In this sense education are engineers applying their skills to carry out a plan or drawing, them, they are artists who are able to improvise and devise new ways of looking at things. (Donald, 2000). However, it is also easy to see why many students resist writing and keeping journals. We might see ourselves as the sort of person who write about our lives and experience in the way Moon (2002) described.

This study therefore tends to explore the attitude of undergraduates students towards the use of journal at the Delta State University Library, Abraka. However, the major problems faced by undergraduate students towards the use of journals are; types of journal publications available to them, problem of awareness of the importance of journals by undergraduate students, lack of acquisition of current journals is different area of specialization, lack of organization of journals in subject area for undergraduate students, Challenges encountered by undergraduate students in the use of journals.

The study become significant to lecturers, students, consultants, information scientists, librarians, etc as they always use journals for diverse purposes which include storing and repacking the contents of information in it to buttress their research as they carry most recent information. Users of the academic libraries can develop and improve their capabilities through the available journals they have. The extent to which this is done will boost the ego of the undergraduates towards the use of journals. It will also serve as a research tool to subsequent researchers who may conduct research work similar to this.

\section{The Concept of Journal}

The term journal according to the advance learners dictionary is a timely publication deals with a particular subject (a scientific journal, trade journal and library and information science journal) on the other hand, the same dictionary sees electronic as a device having or using many small part that works with electronic. The wikipedia of library science sees electronic journals as a journal in an electronic format. The phrase "electronic journal" is defined by Alison (1990:10) as a publication, often scholar that is made accessible in a computerized and distributed over the internet. According to him one electronic journal or e-journal may have a traditional paper (print format) counterpart or historical antecedent. Furthermore a postal on the web services e-journal as a "digital journal" defined it as a digital publication archive online to every through the internet.

The first scholarly journal "journal des scavans" was published as a new medium of communication in 1665 and was soon followed by the philosophical transaction of the royal society (Osborn, 1984). For more than three centuries the journal has played a pivotal role in the creation and transmission of knowledge by serving as the primary me- 
dium of scholarly communication and has remained essentially unchanged in form and function over the lifetime. The costs of producing the paper journal have increased sharply. Developments in computer and communication technology have accelerated. And of course, we have the dramatic explosions of the World Wide Web (WWW) technology increasingly offers the possibilities of using computers and communication networks to create alternative electronic forms of the conventional paper journal. It is possible that these nine forms of computer- bases communication will transfer the scholarly communication system. There is much debate and discussion concerning how the role of the varoud participants in the scholar communication, process including libraries may be redefined in the process. Although electronic journal have been under development since 1976 (Toroft and HIH2 1982), e- journal in their non experimental phase did not begin until 1990, with a fine exception. The first peer- reviewed electronic full e-journal of current clinical trial (OJCCT) Keyhani (1993:1). In he most recently published list and one of the new research projects involving e-journal, Aitchcoch, Carr and Hall 1996 identified "115 scholarly pre-reviewed e-journals in science and technology and there are many more in social science and humanities. These constitute the first wave are likely to be many more scholarly e-journal to come".

An Okenson wrote, "one can fantasize endlessly about "electronic journals" but without active authorship and readership there is nothing" (quoted in Collins and Bergg (1994). We would add "use" to authorship and readership if e-journals are not used, they cannot play an important role in scholarly communication Stephen, Hak and Kin (1996). To this end, Spring (2004:2) some of the early determination to the use of electronic journals involved the system of academic tenure and promotion of cumbersome technology and concern about archiving Bodlen (2003:15) pointed out that the electronic journal would become a viable substitute for print, if only when the scholarly community accepted them. This situation has been mentioned frequently in the literature. Jordan (1995:18) found only $7.47 \%$ of faculty surveyed read electronic journals. Crown and Over felt (1995" 100-703) found in their survey of personnel and tenure policies at fifty universities that electronic publication was not explicitly discounted, but that many respondents were unaware that peer reviews process was used in Butlers (1995:15) indicate that while electronic publication is not overly degraded, contributors themselves felt that it carried less weight than print publication.

However, the mid-1990s situation began to change an evidenced by the involvement of major research universities in scholarly electronic journal products. James Gardner, Vice President and Provost of the University of Manitoba, has noted that the opportunities for evaluation of past publication impact afforded by the electronic medium make it a valuable tool in assessing the work in 1993 issued a statement on computer support, which urged communicates for tenure and promotion to consider computer related work as an integral part of a candidate's dossier and to evaluate it according to its merit in the discipline. In 1999 universities such as Rutger included guidelines for citing electronic publication as their instructions for tenure and promotion. It was becoming generally accepted that a candidate for tenure promotion might include electronic journal in his dossier. The fact that universities are respected publishers have become involved in electronic journal certainly gives credibility to the medium. The online computer library centre (better known as OCLC) was a pioneer in this investment with strictly online journal current clinical trials. It is now offering on array of electronic journals and has been joined in the field of electronic publishing by several similar ventures such as institution for science formation (151) Elseuier and Ebsco.

Further evidence on academic acceptance of electronic journal has been found in the fact that so many prestigious institutions have signed the Budapest Open Access (BOA) (Budapast Open Accessed Initative Website http://soros.org. openaccess/viewcfm). Accessed October 18, 2010) and have become members of the Scholarly Publishing and Academic Resources Coalition (SPARC) spread website (http://www. or/org/core/inex.asp) page $=$ bi accessed (October 1, 2009). Over 200 prominent organization and universities have signed in support of BOAI which has its goal "the World Wide electronic distribution of the peer-viewed journal literature and completely free and unrestricted access to it by all scientist, scholarly teachers, students and other curious minds. Source Budapest Open Access initiative (October 2003). The framer of the initiative saw technology as the means for accomplishing this goal. SPARC, coalition of universities research libraries and organization was found in 1998 as an official project of the Association of Research Libraries. The purpose of SPARC is provided broad cost effective access to peer-previewed scholarship. SPARC intends to accomplish its goals by education of stakeholders in scholarly communication, advocacy and incubation of alternatives to commercial to access publication

\section{The types of Journal Publication}

The move of journals from print to electronic has affected the serials management in libraries, and some of those changes affect how library users incorporate booking at journals within their patterns of work. Bonthron (2002). Early studies on electronic journals emphasized the need for electronic journals to emulate the usefulness of print journals (Shawarzwalder 1998). Although, acceptance depended on the way they would interface with users working environment. Oslen (1994), Rogers (2001) at Ohio State University Cities, for example, a change from 200 to over 300 electronic journals as a move towards critical mass, at which point users would be happy to see print subscriptions cancelled. Many of the research studies do not address how the journal and periodical literature was used by academic skill, researchers and students in different disciplines prior to the introduction of electronic journal trials, and some of the differences found (Pullinger, 1999). 
Libraries have used various methods of promoting journals to their users and methods include diral access from the online public access catalogue (Chaney, Bullard and Christiansen, 1999). Rogers (2001) stated that there is special way of organizing and accessing journals for their discipline by the undergraduate which had special responsibility for teaching and learning in that discipline. An in-depth study with academic staff and research students in the sciences bookmaking sites for bibliographic databases, journals collections are organized.

Undergraduate students' organization and use of journals are accessed from the data in two ways. Justeis (2011) noted that undergraduate needs to be advised how to organize and access some electronic journals through the database. Probably for one of the assignment which was for a human resource module and the tutor recommended to us various academic journals and text which are available online. Those who have been trained in use of an electronic journal web page were prepared to use the page particularly when searching from home. According to Hiemstra (2000), a variety of journaling types and formats have been developed over the years. A literature search produces a plethora of types, descriptions and examples. Most students even use them to move beyond the knowledge and skills available through normal classroom activities. These are;

\subsection{Learning Journals}

A learning journal typically is a hand written in a notebook or on a pad of papers as a means for recording thoughts, reflections, feelings, personal opinions, and even hopes or fears during an educational experience. However students can use a tape recorder or computer keyboard.

\subsection{Diaries}

A diary is typically a notebook, booklet of blank pages, or any source for students to record thoughts, reactions to learning experiences and even innermost fears about a learning activity. Some learners prefer to create electronic or audio diaries. Regardless of the particular format, entries of daily experience, insights, and problems often are made. Diary writing usually involves the unstructured, chronological recording of the events of a person's life as they are perceived.

\subsection{Autobibliographies}

Is another type of journals as stated by Bethards (2007) meaning life stores and memories which reveals the heart and soul of human existence. Autobiography focuses on self assessment, life stories typically access someone else life but can be used personally and memories takes a more informal approach to telling a life story.

Spiritual journals according to O'Hanlon (2007) is another type of journals. A spiritual journal usually is somewhat different than a regular journal or diary. It normally involves recording personal reactions to spiritual or religious matters. This particular approach may not match the needs of many undergraduate students, especially if they are taking a course for credit, but occasionally a student with deep religious convictions will find the technique a useful companion to their study activities. Spiritual journals can also be used in retreat settings where learners use mechanisms to help improve their self-understanding. He further stated that a professional journal is another type of journal. This can have a very specific purpose in mind. For example, asking a student to keep a professional growth and development journal can be very important, especially as they never completion of a degree programme.

\section{The Awareness of Journals among Undergraduate Students}

Journal awareness as an instructional or learning tool in education has gained cogency during the past three decades. As early as 1965, psychologist Ira Progott and his colleagues begin seeing the importance of journals in enhancing growth and learning. Progott believed what he called an intensive journals process could draw each person's life toward wholeness at its own tempo. It systematically evokes and strengthens the inner capacities of persons by working from a non medical vantage point and proceeding without analytic or diagnostic categories (Progott 1975) cited by Hiemstra (2002).

According to Finley (1020), the importance of integrating journal use across the curriculum is amply documented. From the undergraduates' perspective, there are activities that can trump journal for understanding and supporting the development of student thinking. Journaling in its various forms is a means of recording personal thoughts, daily experiences and evolving insights. The process often evokes conversations with itself, another person, or even an imagined other persons (Sisco 2000). Sisco further noted that journals are tools that aid learners in term of personal growth, synthesis and/or reflection on new information that is acquired. Sisco stated the need for learners to use journals as a means for assisting them obtain the maximum amount of interaction, knowledge and personal growth from their reading efforts to other learning experiences.

Hiemstra (2000) noted that journals promote critical self reflection where dilemmas, contractions and evolving worldviews are questioned or challenged. In the graduate classroom, for example, this may be especially valued results as undergraduates attempt to facilitate a professional development and then reflecting on what that means for a current or expected position can be an important outcome. Hiemstra further noted that some students include portions of a journal or diary in a professional portfolio as a means of demonstrating to prospective or current employers.

According to Bethards (2007), journals enhance the development of personal statement of philosophy or a code of personal ethics. This recognition of personal value, beliefs are the various changes a person undergoes through life is 
combined with a personal philosophy statement, can result in foundational tools useful as guides or mirrors for subsequent professional action or ethical decision making.

There are a number of potential benefits for undergraduates in maintaining some type of journal, diary or $\log$ as stated by Brookfield (2005). Brookfield noted that journals enhance intellectual growth and development. This is achievable by most learners, especially as they gain more experience with the use of journals. Journals enable development and ability to examine new knowledge in critical ways. Brookfield provided more detail on the importance of journals;

\subsection{Personal Growth and Development}

Brookfield emphasized that most important for learners of all the benefits is the enhancement of personal growth and development. Journals can help with such learning goals or expected outcomes as integrating lot experiences with learning endeavours, allowing for a freedom of expression that may be inhibited in a group of setting, stimulating mental development, enhancing breakthrough in terms of new insights, and even planting seeds in terms of future study or research. Basically it is an investment in yourself through a growing awareness of personal thoughts and feelings.

\subsection{Intuition and Self Expression}

Another outcome and importance of journal awareness among undergraduate students are intuition and self expression. This according to Brookfield (2005) is always expected, it is an enhanced ability at self discovery. Learning to trust that inner voice and interpret new thoughts or even dreams can increase self confidence not only in the classroom but in many other settings too.

\subsection{Problem Solving}

Utilizing a journal often helps in the solution of problems. writing and imagining your way through a problem via personal insights and reflections on life experience can be very rewarding.

\subsection{Stress Reduction and Health Benefits}

Bruce (2008) also emphasized that journals are important at enhancing stress reduction and health benefits. There is considerable evidence that journals can improve various aspect of personal health. Bruce describes research with subjects who wrote thoughtfully and emotionally about traumatic experiences and most of them generally experienced improved physical health. In a related view, Adams (2008) also talks about journals as therapy for enhancing psychological healing and growth. Most education students may not need them to release point up emotions, counter anger or frustration, and overcome or reduce the stress or typical in today's busy work world and lifestyle.

However, Adams (2008) discussed a various ways in prior descriptions of journals procedure. It is important however to make explicit the value of journals in helping learner increase their ability to reflect critically on what they are studying or learning.

\section{The Acquisition of Current Journals in Different Areas of Specialization in the Library}

Library science which is often termed library studies, now dominating other areas to libraries, the collection, organization, presentation and acquisition and evaluation are applied by students and non students as well(Wikipedia 2008). Again, Oguniyi (2011) posited that the library is an integral part of any educational institution, most especially at the tertiary level. In the same vein, Popoola (2006) stated that a well stocked and organized library is a pride to any educational institution which will definitely help in meeting its teaching, learning and research needs through availability of contemporary journal publications alongside other library resources. To this end, Nwalo (2003) cited Osborn (1980) to describe journals as publications issued in successive parts at regular or irregular intervals and intended to be continued. There are many types of journals such as educational journals, journals on health, journals on internet, journals on nursing.

Ogunrombi (2007) stated that journals are most important to researchers and undergraduates because much of articles therein are product of research and it any never appear in any other publication. According to Ogunrombi, the backbone of any academic library due to their nature of informational value can not be quantified. Academic and research libraries acquire, organize, store, retrieve and disseminate information contained in journals for researchers, educators, students and other interested persons in their various disciplines.

Akerele (2008) noted that academic libraries must therefore provide the latest and current journals titles in all the subjects/courses covered by its parent institution and also staff and students are expected to make use of the library most especially the serial section of the library to get current information in their chosen field of study. In the words of Olanloku and Salisa (2008), journals are accorded prominence in the library because they provide the latest and current information in a discipline and if people want to be current in their field, they have to read relevant journals. It is therefore a matter of concern to note that pallary number of undergraduates consults journals in the libraries. This could be due to non availability of journals, professionals, recency and other factors. It is in light of this, that this research intends to investigate undergraduates' use of journals. Researches have shown as stated by Brown (2007) that undergraduate students prefer electronic journals to print. Brown, who worked on academic staff use of e-journals found that having access to journal seen as important by undergraduates. Sarasvady (2007) corroborated this further when he posited that undergraduate prefers electronic journals to print ver- 
sion.

On the issue of collection development policy for journals, the Australian College of Physical Education (2007) stressed that the collection policy of the Robert Dunmat library comprises of approximately 400 journals titles in which 80 of these are current subscription. The decision of acquisition of journals depends on the institution policy as stated university of (Aukland 2007).

\section{The Relevance of Organizing Journals in Subject Areas for Undergraduate use}

How students are thinking. Journals are a way to incorporate personal ideas with observation and interference. Students can express their opinion with every experiment. Encourage students to write questions about process or outcome of exploration. (Brown 2007). Journals give students a place to plan, to gather resources and research materials, to do preliminary drawings and to experiment with media; in short to explore and document personal creative processes. On a very basic level, it helps students keep all required and exploratory material together.

\subsection{Assessment and Evaluation Consideration}

The journal can be used as a reference file to help the teacher monitor individual development and progress. Entries should not be evaluated as finished products. The evaluation of journals should emphasize the content. While each journal is unique, good journals share the following characteristics;

\subsection{Personal observations}

\subsection{Questions}

\subsection{Speculations and predictions}

\subsection{Evidence of developing self awareness}

\subsection{Connections between personal experience and new information(University of Auckland 2007)}

A journal is like a good friend who is never too busy to listen. 2004-2006 Saskatoon Public Schools. Nov. 18, 2011.

Journals give other students the opportunity to reflect on their world and expand their awareness of what is happening in their lives. For many students; journals become rich source of ideas for writing. (Kelly 2004).

\subsection{How can I adapt it?}

There are several variations of journals that can be adopted to fit the needs of the classroom;

\subsection{Personal Journals}

These journals allow students freedom to write about their feelings, opinions, expressions and about topics of personal interest. If they wish, undergraduate students may share entries with others.

\subsection{Dialogue Journals}

Dialogue journals are conversations in writing. Most often the conversation is between the students and the teacher or classmates. These journals are interactive - the two conversation partners comment on one authors' entries. These conversations encourage students to express themselves in thoughtful and informal way.

\subsection{Reading Response Journals}

These journals are used to capture students' reaction to books and to track their reading. The entries might include questions, comparisons, evaluation, letters to characters, predictions and comments on style or mood. The goal of writing is to provide students with opportunities to explain their thinking about ideas and then to re-examine their thought processes in solving problems and learning. (Olanlokun and Salise 2008). Using journals could be a great way for the teacher to have a better understanding on mind or alternatively for a wider professional audience possibly for colleagues, a tutor, or an assessor in course in higher education contexts.

\section{The Challenges Encountered by Undergraduate Students in the Use of Journals}

Madnd and Adeniran (2005) gave some of the problems of journals inadequacy as;

1. The publisher might change

2. The content of each issue is different

3. The publication interval varies. Some are biannual, monthly, quarterly, forthrightly, weekly, daily and annually.

4. No planned end to the sequence.

5. They are current and up to date

6 . They are more expensive than books and

7. They are subscribed to. In the same vein, Tedd (2004) wrote on the inherent problem of journals which include:

8. The tendency of journals to change name, divide into two or three separate publications, die or lay dormant for several years.

9. The difficulties in being aware of which issues have not yet been received.

10. Possible changes of publisher.

11. The fact that some journals, especially in research libraries, are not brought but are gifts or exchanged.

12. The physical problems of storing and circulating individual issues, and being aware of when all the issues of a volume have been received and so ready to be sent to binders.

Journals as an indispensable component in an academic library's collections can easily account for $50 \%$ of an annual library materials budget. As more and more budgets are 
spent on journals, their maintenance becomes more and more challenging. On the one hand, the number of journals continues to grow (Brake, Maroan, Stowell and Martin 2005). Another problem of inadequate journal is limited shelf space. One of the biggest problems of using journals is that some undergraduates students imply use them as a way to record the days events. They slip into the routine of writing during entries without reflection or real purpose. (Mark 2007).

\section{Methodology}

This study is based on descriptive survey design method and the population consists of 24, 389 students across different faculties at the Delta state university, Abraka. Among these are:

$\begin{array}{cc}\text { Faculty of arts - } & 2.657 \\ \text { Faculty of science - } & 2.783 \\ \text { Faculty of education- } & 9,364 \\ \text { Faculty of Basic Medical science - } & 3,262 \\ \text { Faculty of social science - } & 6.323 \\ \text { Total- } & 24,389\end{array}$

A random sampling technique was employed for this work. The sample consist of a total number of students from various faculties at the Delta State University which is a total of 24,389 students, out of which, $0.5 \%$ which is 121 students was randomly selected by the researcher to respond to the questionnaire. This is mathematically illustrated thus:

$$
\frac{24389 \times 0.5}{100}=121
$$

Therefore, 121 students will be used as respondents of this research study. The instrument for data collection used for this study is the questionnaire which was given a face and content validity. The questionnaire was administered to users of Delta State University Library Abraka. The respondents read through the questionnaire and it was distributed among users and was retrieved from them. The simple percentage and frequency count was used to interpret the research questions.

Table 1. Gender Distribution of Respondents

\begin{tabular}{|c|c|c|}
\hline Gender & Response & Percentage (\%) \\
\hline Male & 50 & $41 \%$ \\
\hline Female & 71 & $59 \%$ \\
\hline Total & $\mathbf{1 2 1}$ & $\mathbf{1 0 0}$ \\
\hline
\end{tabular}

\section{Discussion and Findings}

The discussion of this research was based on administered 121 copies of questionnaire to users of the Delta State university library and were retrieved back from them

\subsection{Analysis and Interpretation of Undergraduates Use of Journals}

From the above table 1, the gender distribution of respondents shows female $71(59 \%)$ with majority response while male 50(41\%) with minority response. This implies that female undergraduates are more than male undergraduates at the Delta State University, Abraka.

Table 2. Age Distribution of Respondents

\begin{tabular}{|c|c|c|}
\hline Age & Response & Percentage (\%) \\
\hline $14-16$ & 23 & $19 \%$ \\
\hline $17-19$ & 29 & $24 \%$ \\
\hline $20-22$ & 42 & $35 \%$ \\
\hline $23-25$ & 16 & $13 \%$ \\
\hline 26 and above & 11 & $9 \%$ \\
\hline Total & $\mathbf{1 2 1}$ & $\mathbf{1 0 0 \%}$ \\
\hline
\end{tabular}

From the above table 2, the age distribution of the undergraduates, the age bracket of 20-22 years recorded the majority with $42(35 \%)$, while $17-19$ recorded $29(24 \%)$. The age bracket 14-17 recorded 23(19\%). The age bracket 23-25 recorded 16(13\%) while 26 and above age bracket recorded $11(9 \%)$. This implies that the undergraduate students are dominated by age bracket $20-22$ years.

From table 3, the importance of journal awareness to undergraduate students was discussed. $72(60 \%)$ strongly agreed that journal awareness has gained cogency among the undergraduate students, $18(15 \%)$ agreed, while $19(16 \%)$ strongly disagreed and $12(9 \%)$ disagreed in figure (i). figure (ii) shows 56(46\%) strongly agree that journal process draw each persons life towards strength and inner capacity, while $28(23 \%)$ agree $33(27 \%)$ strongly disagreed while $4(3 \%)$ disagreed. Journal use supports undergraduate students thinking as strongly agree by $84(70 \%)$ respondents while $10(8 \%)$ also agreed. $11(9 \%)$ strongly disagreed while $16(13 \%)$ disagreed. In figure (iv) journals promotes critical self thinking as strongly agree by $66(55 \%), 13(11 \%)$ agreed. $29(24 \%)$ strongly disagreed while $13(11 \%)$ disagreed. However, 62(51\%) strongly agree that journals enhance the development of personal philosophy or a code of ethics while $17(14 \%)$ agreed. $24(25 \%)$ strongly disagreed while $18(15 \%)$ disagreed. This implies that the importance of journal awareness among undergraduate students, Delta State University cannot be pushed aside as stated by the following authorities Progott (1975), Hiemstra (2002). Finley (2010), Brookfield (2005). 
Table 3. The Importance of Journal Awareness to Undergraduate Students

\begin{tabular}{|l|l|l|l|l|l|l|l|l|l|l|l|}
\hline S/n & Questions & SA & $\mathbf{\%}$ & $\mathbf{A}$ & $\mathbf{\%}$ & $\mathbf{S D}$ & $\mathbf{\%}$ & $\mathbf{D}$ & $\mathbf{\%}$ & Total & Total \\
\hline i. & $\begin{array}{l}\text { Journal awareness has gained cogency among the } \\
\text { undergraduate students. }\end{array}$ & 72 & $60 \%$ & 18 & $15 \%$ & 19 & $16 \%$ & 12 & $9 \%$ & 121 & 100 \\
\hline ii. & $\begin{array}{l}\text { Journal process draw each person's life towards } \\
\text { strengths and inner capacity. }\end{array}$ & 56 & $46 \%$ & 28 & $23 \%$ & 33 & $27 \%$ & 4 & $3 \%$ & 121 & 100 \\
\hline iii. & Journals supports undergraduate students' thinking. & 84 & $70 \%$ & 10 & $8 \%$ & 11 & $9 \%$ & 16 & $13 \%$ & 121 & 100 \\
\hline iv. & Journal use promotes critical self reflection & 66 & $55 \%$ & 13 & $11 \%$ & 29 & $24 \%$ & 13 & $11 \%$ & 121 & 100 \\
\hline v. & $\begin{array}{l}\text { Journals enhance the development of personal phi- } \\
\text { losophy or a code of ethics. }\end{array}$ & 62 & $51 \%$ & 17 & $14 \%$ & 24 & $20 \%$ & 18 & $15 \%$ & 121 & 100 \\
\hline
\end{tabular}

Table 4. The Acquisition of Current Journals in Different Areas of Specialization in the Library

\begin{tabular}{|l|l|l|l|l|l|l|l|l|l|l|l|}
\hline S/n & Questions & SA & $\%$ & $\mathbf{A}$ & $\mathbf{\%}$ & SD & $\mathbf{\%}$ & $\mathbf{D}$ & $\%$ & Total & Total \\
\hline i. & $\begin{array}{l}\text { Academic libraries provides the latest and current } \\
\text { journals. }\end{array}$ & 61 & $50 \%$ & 32 & $19 \%$ & 19 & $16 \%$ & 18 & $15 \%$ & 121 & 100 \\
\hline ii. & $\begin{array}{l}\text { Undergraduates makes use of current journals in } \\
\text { academic libraries. }\end{array}$ & 72 & $60 \%$ & 15 & $12 \%$ & 12 & $10 \%$ & 22 & $18 \%$ & 121 & 100 \\
\hline iii. & $\begin{array}{l}\text { Academic library acquire, organize, store, retrieve } \\
\text { and disseminate information contained in journals. }\end{array}$ & 121 & $100 \%$ & 0 & $0 \%$ & 0 & $0 \%$ & 0 & $0 \%$ & 121 & 100 \\
\hline
\end{tabular}

Table 5. The Relevance of Organizing Journals in Subject Areas for Undergraduate Students' Use

\begin{tabular}{|l|l|l|l|l|l|l|l|l|l|l|l|}
\hline S/n & Questions & SA & $\mathbf{\%}$ & $\mathbf{A}$ & $\mathbf{\%}$ & $\mathbf{S D}$ & $\mathbf{\%}$ & $\mathbf{D}$ & $\mathbf{\%}$ & Total & Total \\
\hline i & Journals gives students a place to plan. & 91 & $75 \%$ & 10 & $8 \%$ & 5 & $4 \%$ & 15 & $10 \%$ & 121 & 100 \\
\hline Ii & Journals can be used as a reference file. & 22 & $18 \%$ & 16 & $13 \%$ & 63 & $52 \%$ & 20 & $17 \%$ & 121 & 100 \\
\hline iii. & Journals are used to capture students' reaction to books. & 65 & $54 \%$ & 29 & $24 \%$ & 15 & $12 \%$ & 12 & $10 \%$ & 121 & 100 \\
\hline
\end{tabular}

Table 6. Challenges Encountered by Undergraduate Student in the Use of Journals

\begin{tabular}{|l|l|l|l|l|l|l|l|l|l|l|l|}
\hline S/n & Questions & SA & $\mathbf{\%}$ & $\mathbf{A}$ & $\mathbf{\%}$ & SD & $\mathbf{\%}$ & $\mathbf{D}$ & $\mathbf{\%}$ & Total & Total \\
\hline xii. & Elusiveness & 62 & $51 \%$ & 15 & $12 \%$ & 23 & $19 \%$ & 21 & $17 \%$ & 121 & 100 \\
\hline xiii. & Possible changes of publisher & 59 & $49 \%$ & 18 & $15 \%$ & 25 & $21 \%$ & 19 & $16 \%$ & 121 & 100 \\
\hline xiv. & Physical problems of storing & 83 & $69 \%$ & 7 & $5 \%$ & 17 & $14 \%$ & 14 & $12 \%$ & 121 & 100 \\
\hline xv. & Expensiveness & 121 & $100 \%$ & 0 & $0 \%$ & 0 & $0 \%$ & 0 & $0 \%$ & 121 & 100 \\
\hline xvi. & No planned end to the sequence & 24 & $20 \%$ & 29 & $24 \%$ & 49 & $40 \%$ & 19 & $16 \%$ & 121 & 100 \\
\hline
\end{tabular}

Table 7. Types of Journals Publication

\begin{tabular}{|l|l|l|l|l|l|l|l|l|l|l|l|}
\hline S/n & Questions & SA & $\mathbf{\%}$ & $\mathbf{A}$ & $\mathbf{\%}$ & SD & $\mathbf{\%}$ & $\mathbf{D}$ & $\mathbf{\%}$ & Total & Total \\
\hline xviii. & Undergraduate students use electronic journals & 75 & $62 \%$ & 22 & $18 \%$ & 13 & $11 \%$ & 11 & $9 \%$ & 121 & 100 \\
\hline xix. & Undergraduate students use print journals & 82 & $68 \%$ & 15 & $12 \%$ & 19 & $16 \%$ & 5 & $4 \%$ & 121 & 100 \\
\hline xx. & Libraries uses various methods of promoting journals. & 121 & 100 & 0 & $0 \%$ & 0 & $0 \%$ & 0 & $0 \%$ & 121 & 100 \\
\hline xxi. & Variety of journals have been developed over the years. & 121 & $100 \%$ & 0 & $0 \%$ & 0 & $0 \%$ & 0 & $0 \%$ & 121 & 100 \\
\hline
\end{tabular}

From the above table 4 , the acquisition of current journals in different areas of specialization was discussed. 61(50\%) respondents strongly agree that academic library provides the latest and current journals for undergraduate use $23(19 \%)$ agreed while $19(16 \%)$ and $18(15 \%)$ strongly disagreed and disagreed respectively. Figure (vii) shows 72(60\%) strongly agree that undergraduates makes use of current journals on the academic library, $15(12 \%)$ agree also while $12(10 \%)$ strongly disagreed and 22(18\%) disagreed. Figure (viii) recorded that $121(100 \%)$ strongly agreed that academic library acquire, organize, store, retrieve and disseminate information contained in the journals. This signifies that academic libraries truly acquire current and latest journals for undergraduate students' use as maintained by Popoola (2006), Ogunnombi (2007), Akerele (2008) and Brown (2007).

From the above table 5, the relevance of organizing journals in subject areas for undergraduate students use were discussed. Figure (ix) show 91(75\%) respondents strongly agreed that journals gives students a place to plan, $10(8 \%)$ also agree. 5(4\%) and 15(12\%) strongly disagree and disagree respectively. Figure (x) shows 63(52\%) respondents 
strongly disagree that journals are used as a reference file, while $22(18 \%)$ strongly agree. $16(13 \%)$ agree and $20(17 \%)$ disagreed. Figure (xi) shows $65(54 \%)$ revealed and strongly agreed that journals are used to capture students reaction to books, 29(24\%) agreed while $15(12 \%)$ strongly disagreed while $12(10 \%)$ disagreed. This implies that the relevance of organizing journals in subject areas for undergraduates students' use cannot be overemphasized as noted by Brown (2007), University of Auckland (2007), Kuly (2004) and Olanlokun and Saliser (2008).

From the above table 6, the challenges encountered by undergraduate students in the use of journals were discussed. Figure (xii) shows $62(51 \%)$ strongly agree that exclusiveness is a challenge, $15(12 \%)$ agreed while $23(19 \%)$ strongly disagreed and 21(17\%) disagreed. Figure (xiv) shows $83(69 \%)$ strongly agreed that physical problems of storing journals is a challenge, $7(5 \%)$ also agreed. While $17(14 \%)$ and $14(12 \%)$ strongly disagreed and disagreed respectively. Figure (xv) revealed the expensiveness is a major challenge as strongly agreed by $121(100 \%)$. Figure (xvi) shows $49(40 \%)$ strongly disagreed that no planned end to the sequence of journal is a challenge. 24(20\%) strongly agreed while $29(24 \%)$ and $19(16 \%)$ agreed and disagreed respectively. This implies that there are challenges encountered by undergraduate students use of journals as stated by Madu and Adeniran (2005), Tedd (2004) and Martin (2005).

The table 7 above shows the types of journals publication used by undergraduate students. Figure (xviii) shows $75(62 \%)$ journals, $22(18 \%)$ also agree, 13(11\%) strongly disagree while $11(9 \%$ ) disagree. Figure (xix) shows 82(68\%) strongly agree that undergraduate students use print journals, $15(12 \%)$ also agreed, while $19(16 \%)$ and 5(4\%) strongly disagreed and disagreed respectively. Academic libraries uses various methods of promoting journals as stressed by $121(100 \%)$ of the respondents. $121(100 \%)$ also strongly agreed that variety of journals have been developed over the years. This implies that there are kinds of journal publications used by undergraduate students as asserted by Oslen (1994), Rogers (2001), Pullinger (1999), Hiemstra (2000).

\section{Research Findings}

From the analysis carried out, the researcher discovered the following;

i That Journals are used for diverse purpose among undergraduate students.

ii That Journals enhance the development of personal philosophy in a code of ethics.

iii Undergraduate students makes use of current journals in academic libraries.

iv Journals can be used to capture students reaction to books.

v Undergraduate students use electronic journals as well as print journals.

vi Undergraduate students uses various method to promote journals in their research work.

\section{Recommendations}

Due to the finding gotten in this study, the researchers recommend the following;

i That the use of journals should be encouraged among the undergraduate students in Delta State University.

ii More current journals should be provided for undergraduate students' use.

iii Funds should be provided to purchase more journals in Delta State University for undergraduate students' use.

\section{REFERENCES}

[1] Adams, K. (2008). The way of the Journal: A Journey Therapy Workbook for Healing ( $2^{\text {nd }}$ ed.) Towson, MD: Sidran Press, 2008.

[2] Answer.com (2011). Academic use of Journals. Journals of library, Archival and Information Science, Vol.10. No 2.

[3] Bethrads, B. (2007). The Dream Book: Symbols for Self-Understanding (Rev.ed). Boston Element Books, 2007.

[4] Bolton, G. (2005). Reflective Practice and Professional Development. 2c. London: Safe, popular tent that explores how practitioners can critically engage with action and feelings.

[5] Bonthron, K.A. (2002). Usage of Electronic Journals by Academics: A Case Study MSL Dissertation. Aberystwyth: university of Wales Aberystwyth.

[6] Brookfield, S.O. (2005). Developing Critical Thinkers: Challenging Adults to Explore Alternative Ways of Thinking and Acting. San Francisco, Jossey Bass, 2005

[7] Brown, Jeff (2007). Use of E-journals by Academic Staff and Researchers at LoughttonoughUniversity. Available at: http://www.iboro-ac-uk/library/about/PDFsle-journal-survey

[8] Bruce, R. (2008). "Strange but True: Improve your Health through Journaling, May, 2008. Web Address: Available at:[http://www.selfhelpmagazine.com/article/nodel/442]

[9] Finley, T. (2010). The Importance of Student Journals and How to Respond Efficiently. Available at:

http://www.edutopia.org/ student_journal_efficient teacher resp.

[10] Hiemstra, R. (1998). Trandating personal Values and Philosophy into Practical Action. In R.G. Brouckett (ed.) Ethical Issues in Adult Education. New York: Teachers College Press.

[11] Hiemstra, R. (2000). Techniques, Tools and Resources for the Self-Directed Learner. March 2000. Web Address: Available at; http://www.distance.syr.edu/sdtools.html.

[12] Hiemstra, R. (2001) Uses and Benefits of Journal Writing. In LM. English and MA. Gilen, (Eds), Promoting Journal Writing in Adult Education (New Directions for Adult and Continuing Education, No. 90, Pp. 19-20) San Francisco: Jossey - Bass.

[13] Hilton, L. (2005). Academic Journals -Sample Article, Professional Journal General/Subject Journals Resources. 
[14] Holy, M.L. (1989). Writing to grow, keeping a personal professional journal, Pertsmouth, New Hampshire: Heineman.

[15] Klung, R. (2002). How to keep a spiritual journal. A guide to Journal Keeping for Inner growth and personal discovery (rev.ed) Minnapolis: Augsburg. Now in its fourth edition.

[16] Madu, E.E. and Aderian T.N. (2005). Information technology uses and preservation of Resources in Libraries and Information Centres. Ibadan: EVI Coleman P. 117.

[17] Mark, S. (2007), Keeping a Learning Journal; the Encyclopedia of Informal Education, Available at: wwwinfid.org/research/ keeping a journal.html.

[18] Nwalo, K.W. (2003). Fundamentals of Library Practice: a Manual on Library Routine. Ibadan stirling-Horden. P. 9.

[19] O'Hanlan, C. (2007) The Professional Journal, Genres and Personal Development in Higher Education. In S. Hollingsmorth (ed.), International Action Research: A Casebook for Educational Reform. London: The Falmer Press, 2007.

[20] Ogunombi, S.A. (2007). Serials Selection and Deselection: A Survey of Nigerian University Libraries. African Journal of Library, Archives and Information Science Vol. 9. No. 1. P. 33.

[21] Olanlokun, S.O. and Salisa T.M. (2008). Understanding the Library: A Handbook of Library Use. Lagos: Concept. P. 47.

[22] Oslen, J. (1994). Electronic Journals: Implications for Scholars. Learned Publishing, 7(3), (6) - 176.

[23] Popoola, M.O. (2006). Definition, Aims and Objectives of Library. In Library Education Series ed. Mathew O. Popoola: Akure: Molove Educational P. 1.
[24] Progott, A.J. (1975). At a Journal Workshop. New York: Dia Logue House Library 1975. Available at: http://www.distanc e.syr. edu/ journal/i.html.

[25] Pullinger, D. (1999). Academics and the new Information Environment: The Impact of Local Factors on use of Electronic Journals. Journal of Information Science 25(2), 164-172.

[26] Rogers, S. (2001). Electronic Journal Usage at Ohio State University. College and Research Libraries, 62(1), 25-34.

[27] Sarasuady, S. (2007). Study of the Use of Electronic Resources for Implementing Library Consortium (India).Available at: http://www.isica.In/serial/consortial/CB 50).pdf

[28] Schwarzwalder, R. (1998). What we have learned from TULIP and Red. Sage. Database, 21(3), 63.

[29] Sisco, B. (2000). Individualizing Instruction. Making Learning Personal, Empowering, and Successful. San Francisco: Jossey - Bass, 2000.

[30] The Australian College of Physical Evaluation (2007) Library Collection Policy. Available at: http://www.Acpc.Edu.An/fil es/library/ collection \%20 Development.

[31] University of Canterbury (2011). The significance of journals in the academic environment. Journal of Information Science, Vol 4, No 5.pg 3-7

[32] Khey (2002) Emergence of E-journals in the $21^{\text {st }}$ Century. African Journal of Library, Archives and Information Science Vol. 9. No. 1. P. 33.

[33] Moon G. (2010) Opportunities and Strategies for Change in Education. In Ahnet, M., and Galble, E. (eds.), pp. 23-27. 